\title{
Stock Identity of Elasmobranchs in the Northeast Atlantic in Relation to Assessment and Management
}

\author{
M. G. Pawson and J. R. Ellis \\ Centre for Environment, Fisheries and Aquaculture Science, Lowestoft Laboratory \\ Pakefield Road, Lowestoft NR33 0HT, United Kingdom
}

Pawson, M. G., and J. R. Ellis. 2005. Stock Identity of Elasmobranchs in the Northeast Atlantic in Relation to Assessment and Management. J. Northw. Atl. Fish. Sci., 35: 173-193. doi:10.2960/J.v35. $\mathrm{m} 480$

\begin{abstract}
Fish stock assessment requires that those parts of a species' range can be identified in which the effects of exploitation in particular fisheries are apparent. Thus, fisheries are monitored and regulated in management units largely determined by the distribution of fisheries, areas which may or may not coincide with biological self-perpetuating units. There are several methods of identifying fish stocks, including the interpretation of distribution and relative abundance, tagging studies, genetic analyses and spatial variation in morphometrics, life-history parameters, parasites and contaminants. The natural variability and difficulty in measuring life history and morphological characteristics at the population level suggest that these are not good indicators of stock separation for elasmobranchs. Information on population demography does, however, reveal the relationships between fisheries and resource, and indicates where sampling programmes for the collection of stock assessment data should take place. Tagging studies, in particular, can indicate a stock's main range and migrations, if linked with a good description of the fisheries that are involved with its exploitation. The environmental parameters associated with the distribution of a species are also a useful guide to the likely boundaries of movement. In this paper, we discuss the utility of these approaches to delineate areas to be used for stock assessments of elasmobranchs, and show how biological and fishery information has been used to describe the stock identity for six case study species in the Northeast Atlantic.
\end{abstract}

Key words: assessment, elasmobranchs, management units, NE Atlantic, stock identity

\section{Introduction}

The majority of fisheries in the Northeast Atlantic are monitored and regulated in areas that are delineated by the International Council for the Exploration of the Sea (ICES) (Fig.1), and the abundance of the more important commercial teleost species and their response to exploitation are assessed as stock management units within these areas. For fisheries management purposes, the stock unit is conventionally described by the extent to which the effects of exploitation in a particular fishery are recognisable through a species' population (see Harden-Jones, 1968). Ideally, this management unit should also have a high degree of biological integrity, particularly when planning the collection of data to be used in stock assessments.

Whilst there is a need to ensure conservation of habitats, prevent the loss of genetic diversity and minimise the selective effects of fishing (Ryman, 1991), the priority for management of fisheries that take elasmobranchs is population conservation. To achieve this, we must be able to separate and identify stocks. The aims of this paper are to discuss the concept of "management stocks" and the relative merits and disadvantages of the various techniques used to identify such stocks for elasmobranch fishes, and to illustrate this by showing how different sources of information have been used to delineate stock assessment units for six case study species in the European DELASS project (Pastoors, 2004). Recommendations for future studies are also given.

\section{Methods of Stock Identification}

There are several approaches to the biogeographical identification of stocks of commercial teleost fish, including studies on the distribution and relative abundance of various life-history stages, tagging studies, population genetics and examination of spatial variation in natural markers (e.g. parasites), meristics, morphometrics and life-history parameters (reviewed by Pawson and Jennings, 1996). Such general approaches are also applicable for elasmobranch species.

\section{Distribution and Abundance}

Data describing the distribution and relative abundance of fish in their various life-history stages can be used to recognise and chart areas used by different stocks. Landings data from commercial fisheries may sometimes provide an indication of general spatial and temporal 


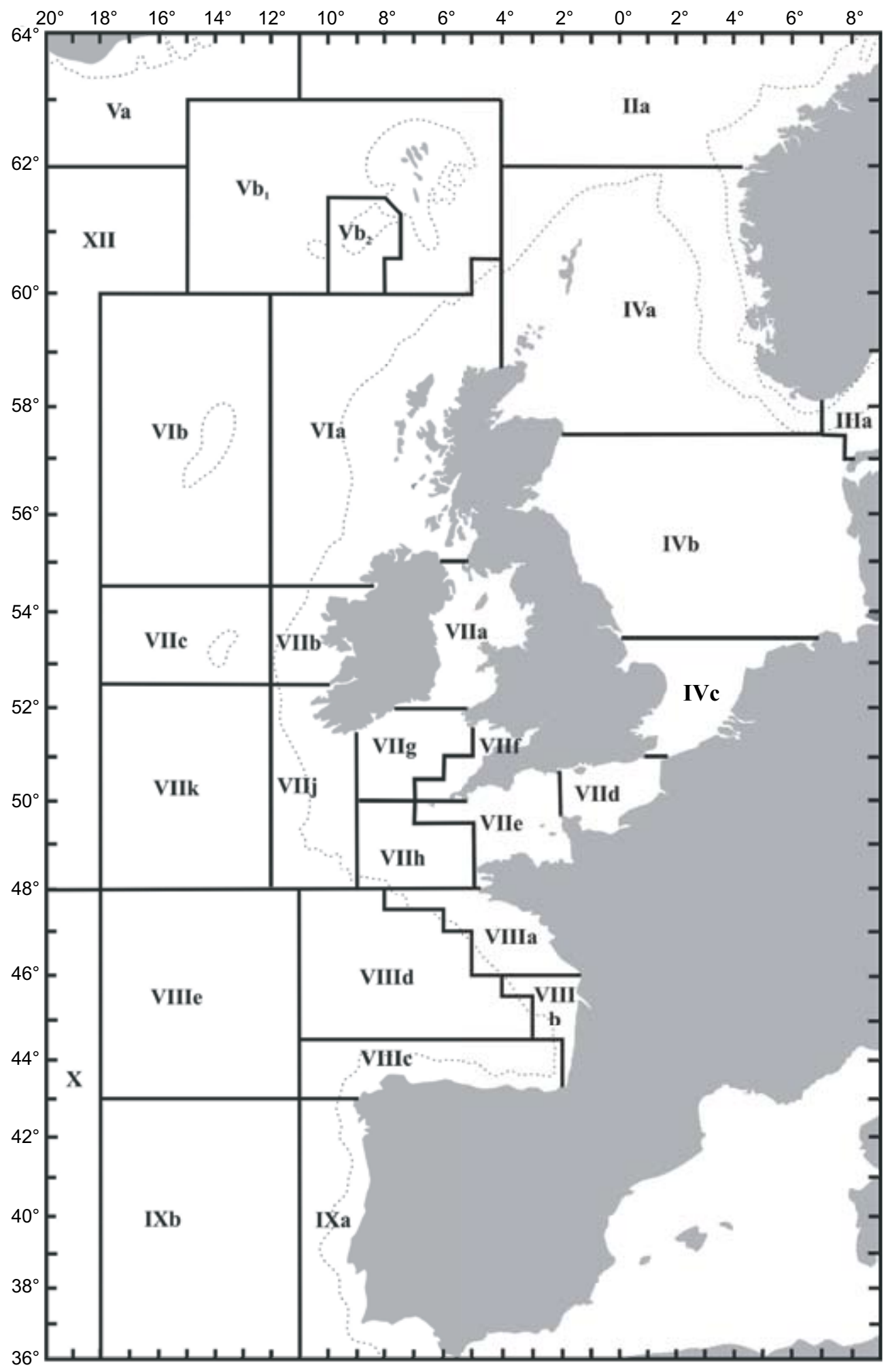

Fig. 1. ICES Divisions in the Northeast Atlantic. 
patterns in distribution, providing that the dynamics of the fishing fleets are also known. Such data may cover extensive areas, but this gives rise to several problems. First, in order to obtain indices of relative abundance, landings data must be standardised to allow for variations in fishing effort in both directed and non-directed fisheries, where gear selectivity and efficiency are usually unknown. Even then, changes in extent and location of areas fished over time, coupled with changes in fish distribution due to migrations or population status, can cause commercial catch rates not to reflect stock abundance. Second, fishermen may discard a proportion of the catch at sea, and this will not be recorded in official landings statistics. Thirdly, elasmobranchs species are frequently grouped in landings statistics (e.g. "skates and rays", "dogfishes and hounds" and "deep-water sharks"), thus preventing any species-specific analysis. Nevertheless, abundance indices for some species can be calculated for some métiers (i.e. fishery units characterised by gear and species catch composition), where landings data are good and fishing effort can be weighted by the power of the vessel or other factors that correct for catching power.

Groundfish surveys are potentially valuable for the study of stock movements, structure and distribution, because the fish captured can be identified to species and catch rates are based on standardised sampling at known survey sites. Whilst the gear used may not be the most efficient means of capturing the species in question and abundance indices are often derived from surveys by different vessels at various times, they can provide good spatial information on a species' general distribution and relative abundance and may be designed to cover the entire stock distribution (Ellis et al., 2004). However, relatively few such studies describe the distribution of breeding, spawning/pupping and nursery grounds. Whilst nursery areas for coastal species may be easily identified if they are located in accessible inshore areas and the juveniles are present at high densities, the distribution of juvenile deep-water sharks in particular is poorly known. Furthermore, the relationships between nursery areas and the adult stocks to which the juveniles subsequently recruit are frequently assumed on the basis of geographical location, but understanding this relationship is a vital component in understanding stock integrity. Such information is increasingly relevant to fisheries management because, as stocks are fished more intensively, juvenile fish frequently form a major and relatively unpredictable proportion of the catch. Moreover, knowledge of the relative abundance of juvenile fish is often the best evidence of stock status (i.e. breeding success).

Unfortunately, stock identification of elasmobranchs is rarely the primary aim of groundfish surveys, many of which were originally designed to sample the more important teleost stocks and, therefore, may not cover the appropriate areas for the various life-history stages of elasmobranchs. Nevertheless, trawl survey CPUE has been used to study the relationships between thornback rays (Raja clavata) in the North Sea and English Channel (Pastoors, 2004).

\section{Parasites}

Fish may become infected by parasites in specific geographic regions during their life, therefore "marking" the fish with an identifiable natural tag indicating the habitat occupied previously, and which may allow it to be distinguished from other fish with different origins. Thus, investigations of the parasite assemblage of fishes may provide information about their life cycle, movements and stock identity (Williams et al., 1992; MacKenzie and Abaunza, 1998). The use of parasites as natural tags offers several advantages over artificial tags. Fish only need to be caught once, thus maximising sample sizes, whereas, when fish are tagged artificially, only a small proportion of these fish may be recaptured, recaptures may be spatially biased, and artificial tags may affect the behaviour of the fish. Parasites are also cheaply sampled, and can provide preliminary information to aid the design of more expensive and complex population sampling and tagging studies. Furthermore, parasites are found in those species that cannot be marked effectively using artificial tags (e.g. rare, delicate and deep-water species).

To interpret the results of parasite studies, it is important to know parasite longevity in the host and the capacity of parasites to infect fish at different stages of their life history. The infective stages should also have a discontinuous distribution in space and time (Lester, 1990). Whilst parasite studies may be validated using conventional tagging data, parasites also share some of the disadvantages associated with artificial tags. In particular, they will not permit stock boundaries to be recognised when sampling effort is low, or if the infection by a parasite is not uniform throughout a particular fish stock.

Although there are many studies describing the parasite fauna of elasmobranchs, they have seldom been used to identify stocks (Caira, 1990). Watson and Thorson (1976) examined the parasites of elasmobranchs in Lake Nicaragua, and confirmed that specimens caught in freshwater also occurred in the Caribbean Sea. McVicar (1977) found that, although a similar range of parasite species was found in the spiral intestines from cuckoo ray Leucoraja naevus caught off Plymouth and Aberdeen, U.K., the intensity of cestode infection was considerably higher at Plymouth, and whilst Phyllobothrium piriei were observed in $98.5 \%$ of specimens from Aberdeen, no 
fish from Plymouth contained this cestode. Moore (2001) examined lesser-spotted dogfish Scyliorhinus canicula from three sites around England and Wales (Cardigan Bay, Plymouth and the Solent) and suggested that larval anisakid nematodes may be useful stock indicators.

\section{Chemical Contaminants}

Fish that spend part of their life cycle in chemicallycontaminated water may absorb or ingest these chemicals, which may remain in certain body tissues and provide an indication of the former life-history of the fish. Hence, it is possible that fish could be linked to stocks by the presence or concentration of contaminants that are distributed heterogeneously in the geographical range of the species in question (Dutil et al., 1985). However, few such sources are available in the open marine environment, which may restrict the use of contaminants to identify marine elasmobranch stocks. Leah et al. (1991a,b) examined spatial variation in mercury levels in the muscle tissue of $S$. canicula caught in the Irish Sea, and suggested that there were "several major populations ... within the study area". As with parasites, the use of contaminants as natural markers can provide valuable supporting evidence, but may not be suitable as a sole method of stock identification.

\section{Tagging Studies}

Elasmobranchs have been subject to conventional tagging studies since the 1930s (e.g. Steven, 1936). Parker et al. (1963) provided a comprehensive review of marking methods, whilst Kohler and Turner (2001) have recently reviewed tagging studies using sharks, which appear to be robust to tagging operations (e.g. Heupel and Bennett, 1997).

The principal tagging methods adopted for studies of stock identification and migration in elasmobranchs have been those using serially-coded external tags. The success of such studies depends greatly on tagged fish being recaptured and returned, and many factors are known to affect this. These include the method of capturing and handling fish (Seber, 1973), choice of tag (Pawson et al., 1987), the condition of the fish after tagging (Beverton and Bedford, 1963), the extent to which tags are shed (Xiao et $a l ., 1999)$ and the publicity and reward systems employed (Wise, 1963). Olsen (1984) reported that the return rate of tagged Galeorhinus galeus increased when fish were tagged both internally and externally.

As with any other method of stock identification, successful interpretation of the results relies on knowledge of the sampling regime, where fish are caught for tagging and recaptured. Whereas tagging studies can provide valuable data for examining movements, migrations, longevity and growth of elasmobranchs, their application to identify- ing stocks has been limited (Kohler and Turner, 2001). Tagging studies can, however, help to support or refute hypotheses on stock identity, provided that sample sizes are sufficient and the overall distribution of the species in question and its fisheries are known (e.g. Vince, 1991).

There have been several co-operative elasmobranchs tagging programmes. The National Marine Fisheries Service in United States runs a Co-operative Shark Tagging Programme (CSTP) (Kohler et al., 1998), and results from this extensive study have been used, for example, to support the hypothesis that there is one stock of blue shark Prionace glauca in the North Atlantic. In contrast, no transatlantic movements of porbeagle Lamna nasus were recorded, suggesting that porbeagle in the Northwest and Northeast Atlantic should be assessed and managed independently.

Ultrasonic telemetry has been used to examine the short-term movements of elasmobranchs since the late1970s (Sundström et al., 2001), providing information on vertical and horizontal movements, habitat utilization and activity space. However, such studies rarely provide information on stock structure. Recent advances in the design of archival tags (Metcalfe and Arnold, 1997) that record and store information on water depth, temperature and light levels, from which latitude and longitude can be estimated, has provided more comprehensive data on the movements and spatial dynamics of free-ranging elasmobranchs (e.g. West and Stevens, 2001; Boustany et al., 2002; Buckley and Metcalfe, 2002). A current study on basking shark Cetorhinus maximus movements on the European shelf (Sims et al., 2003) is a case in point.

\section{Meristics and Morphometrics}

The meristic characters that may be used to distinguish elasmobranch stocks include the structure of hard parts (e.g. dermal denticles, claspers and fin spines) and counts of serially repeated elements such as vertebrae, teeth and rings in the spiral valve. Vertebral counts are available for several species of elasmobranch (e.g. Springer and Garrick, 1964), although there is generally insufficient data to accurately determine the magnitude of spatial variation. Gardner and Ward (1998) reported a gradual increase in the mean number of precaudal vertebrae of Mustelus antarcticus from 82.7 (range: 78-86) off Tasmania, to 85.7 (80-89) off Newcastle (New South Wales) and 88.3 (79-94) off Townsville (Queensland), though it was unclear if this cline was due to environmental or genetic factors. It should also be noted that, whilst the mean counts of meristic characters may be significantly different for samples from separate populations of a species, the allocation of a single fish to a specific stock may not be possible, because intra-stock variation 
in individual meristic counts can be almost as large as inter-stock variation.

Comparatively few studies have examined geographical differences in body morphology (e.g. Strasburg, 1958; Hazin et al., 1991) and, although minor differences in some body dimensions have been reported, statistical analyses are often restricted due to low samples sizes. Furthermore, in the absence of organised data collection, most studies have utilised published studies, which may introduce unknown bias. Whereas significant differences in the morphometrics of sharks have been described between ocean basins, their utility within oceans may be more limited.

Many elasmobranchs are known to exhibit sexual dimorphism and ontogenetic variation in meristics and morphometrics, as well as the spatial variation that may or may not be related to stock structure. Hence, large sample sizes may be required to elucidate morphometric differences between stocks and, given the large size and relatively low abundance of many elasmobranch fish, the collection of sufficient biological material may be logistically difficult. Furthermore, the methodology may not be validated without the support of complementary studies describing the interactions between genotype, environment and stages of development (Ihssen et al., 1981).

\section{Genetics}

Observations of differences in morphology and lifehistory patterns among con-specific fish populations led to the expectation of genetic differentiation within many fish species, the basis for the "genetic stock": a reproductively isolated unit which is genetically different from other stocks (Jamieson, 1974). The results of genetic studies are assumed to provide a reliable basis for stock identification, because they consider fixed genotypic differences between individuals and stocks, surviving successive generations within stable breeding populations, rather than phenotypic differences that may be environmentally influenced (Ryman et al., 1984; Grant and Utter, 1984; Utter 1991). Though genetic analyses may fail to provide evidence of stock separation, this does not necessarily indicate that there are no components within a sea area that have sufficient reproductive integrity to be treated as stocks for management purposes. Indeed, some species' populations may comprise a number of stock units that have sufficient integrity in the medium term to be managed independently, since they respond independently to the effects of exploitation. The low level transfer of individuals between stocks sufficient to maintain genetic homogeneity within the population as a whole may have little consequence to fishery managers. Carvalho and Hauser (1994) reviewed the genetic tools that have been used to provide information on fish stock structure.

There are few published studies that have examined genetic differences in elasmobranch species (Heist, 1999). Sharks were originally regarded as exhibiting low genetic variation (Smith, 1986), and some studies have reported as much genetic variance within areas as between areas (e.g. Lavery and Shaklee, 1989). Nevertheless, as molecular techniques have improved, more recent studies have provided evidence for spatial genetic differentiation in sharks.

Heist et al. (1996a) reported significant differences in the mitochondrial DNA haplotypes of mako shark Isurus oxyrinchus collected from the North Atlantic, South Atlantic and Pacific Oceans. Pardini et al. (2001) observed significant differences in the mitochondrial DNA control region between Carcharodon carcharias from Australia/New Zealand and South Africa. On a more regional scale, Gardner and Ward (1998) observed significant differences in the mitochondrial DNA and vertebral counts of Mustelus antarcticus caught off the southern and western coasts of Australia, though further work is required to determine whether the observed spatial differences are due to discrete stocks or simply reflect a latitudinal cline. Other species for which genetic data are available include Rhizoprionodon terraenovae (Heist et al., 1996b) and various carcharhiniform sharks (Lavery and Shaklee, 1989; Heist and Gold, 1999).

\section{Life-history Parameters}

Individual life-history traits (e.g. growth rate and size/age at maturity) can be described parametrically, although their plasticity in response to short-term environmental variation may restrict their utility for differentiating stocks. Furthermore, it is not easy to collect samples that provide results that truly represent the population of species that have a wide geographical range, and apparent variation in life-history parameters can be due to inadequate sampling. The utility of published studies to provide life-history parameters for different geographical areas may also suffer from variations in sampling protocols (e.g. catching gear) and the seasonality of data collection.

Geographical variation in both reproductive and growth parameters has been reported for elasmobranch species (e.g. Parsons, 1993; Taniuchi and Tachikawa, 1999), but it is often unclear whether this is a response to their local environment, to the effects of exploitation, or the existence of genetically discrete stocks. Accordingly, such methods may not be a reliable means by which to 
define stocks in the long-term. As with meristic and morphometric techniques, life-history analyses may indicate differences between fish sampled from discrete regions, but are unlikely to enable small samples of fish to be identified to specific stocks. Thus, they have limited use in areas where stocks mix.

\section{Stock Identity of Six Case-study Elasmobranchs}

The following section summarises available information for six commercially-important case-study species in the North Atlantic, and highlight some of the problems encountered in identifying stock units with which to undertake preliminary stock assessments under the DELASS project (Anon., 2003). These species represent various taxonomic and ecological guilds of elasmobranchs, with varying degrees of data quality and availability (Table 1).

\section{Wide-ranging Pelagic Shark: Blue shark}

Distribution, population demography and fisheries. Blue shark Prionace glauca is a circumglobal, pelagic shark that typically occurs in waters of $7-16^{\circ} \mathrm{C}$ from the surface down to the thermocline, although they make regular descents to deeper waters (200-600 m) (Carey and Scharold, 1990). In the western Atlantic it occurs from Newfoundland to Argentina, and in the east- ern Atlantic from Norway to South Africa, including the Mediterranean Sea (Compagno, 1984a).

Sexual segregation in $P$. glauca has been reported in the Atlantic. On the Grand Banks and off Newfoundland, $86 \%$ of catches were male (McKenzie and Tibbo, 1964), whereas female-biased sex ratios of 1:13 and 1:55 were reported off south-western England (Stevens, 1974) and south-west Ireland (Crummey et al., 1991) respectively. McNaughton et al. (MS 1998), however, reported approximately equal numbers of males and females in the deeper waters offshore from Southwest Ireland. Juveniles feature predominately in the catches taken south west of the UK, in contrast to larger mature fish found off the Canary Islands and Portuguese coast (Muñoz-Chapuli, 1984).

In the Northeast Atlantic, P. glauca is taken mainly as a by-catch in international surface long-line and driftnet fisheries targeting tuna and billfish, operating from the Celtic Sea south to the west coast of Africa. Up to $82 \%$ of $P$. glauca taken in French and Spanish fisheries are discarded due to its low value compared to that of swordfish Xiphius gladius and other sharks (e.g. mako Isurus oxyrinchus) (Vas, 1995; Mejuto, MS 1985). They are also taken in local, directed long-line fisheries in the southern Bay of Biscay and off the shelf edge in the Celtic Sea, west of Ireland and off Southwest England, where

TABLE 1. A summary of the availability of data with which stock units have been identified in six case study species considered by DELASS (blank: No published information; 1: Some data available, but further data/analyses required; 2: Data available and sufficient).

\begin{tabular}{|c|c|c|c|c|c|c|}
\hline $\begin{array}{l}\text { Stock identity } \\
\text { information }\end{array}$ & $\begin{array}{l}\text { Centrophorus } \\
\text { squamosus }\end{array}$ & $\begin{array}{c}\text { Centroscymnus } \\
\text { coelolepis }\end{array}$ & $\begin{array}{l}\text { Squalus } \\
\text { acanthias }\end{array}$ & $\begin{array}{l}\text { Scyliorhinus } \\
\text { canicula }\end{array}$ & $\begin{array}{c}\text { Prionace } \\
\text { glauca }\end{array}$ & $\begin{array}{l}\text { Raja } \\
\text { clavata }\end{array}$ \\
\hline Landings data & 1 & 1 & 2 & 1 & 1 & 1 \\
\hline Survey data & 1 & 1 & 1 & 2 & 1 & 2 \\
\hline - Distribution & 1 & 1 & 2 & 2 & 2 & 2 \\
\hline - Nursery areas & & & & 1 & 1 & 2 \\
\hline - Spawning areas & & & & 1 & & 1 \\
\hline Tagging & & & 2 & 1 & 2 & 1 \\
\hline Migrations & & & 2 & 1 & 2 & 1 \\
\hline Life history: Age & & & 1 & 1 & 1 & 1 \\
\hline - Length & & & 2 & & & \\
\hline - Growth & & & 1 & 1 & & \\
\hline - Maturity & & & 1 & 1 & & \\
\hline - Fecundity & 2 & 2 & 2 & 1 & 2 & 1 \\
\hline Parasites & & & 1 & 1 & 1 & 1 \\
\hline Genetics & & & & & & 1 \\
\hline Behaviour & & & & & & \\
\hline
\end{tabular}


they are also the target of recreational anglers, especially during the summer.

Reproductive biology. Prionace glauca is placentally viviparous, and detailed accounts of its reproductive biology are available for the Northwest Atlantic (Pratt, 1979) and Northeast Atlantic (Tucker and Newnham, 1957; Stevens, 1974, 1976b). For North Atlantic populations, Pratt (1979) estimated 50\% maturity in males was attained at $183 \mathrm{~cm}$ fork length $\left(L_{F}\right)$, and that females passed through a sub-adult phase at $145-185 \mathrm{~cm} L_{F}$, whilst Castro and Mejuto (1995) reported that females matured at $220 \mathrm{~cm} L_{F}$.

Estimates of fecundity in the Northwest Atlantic (Backus, 1957), central Atlantic (Castro and Mejuto, 1995) the Northeast Atlantic and Mediterranean (Tucker and Newnham, 1957) are similar, at 1-75. The gestation period has been estimated between 9-12 months (Suda, 1953), and the absence of gravid females in inshore waters may indicate that parturition may occur offshore (Stevens, 1975; Pratt, 1979; Draganik and Pelczarski, 1984). Pratt (1979) found that gravid females in the Atlantic had embryos in the same stage of development. The maximum length of embryos has variously been reported as $43 \mathrm{~cm}$ in the North Atlantic (Aasen, 1966).

Growth: The few studies on age and size of $P$. glauca in the North Atlantic provide little evidence of geographical differences in growth parameters, though Tanaka et al. (1990) suggested that any variance in the data may in part be due to preparation technique, reader accuracy and precision, and sample size and bias, as well as natural individual variation. The maximum size reported in the Atlantic has varied from $263 \mathrm{~cm}$ total length $\left(L_{T}\right)$ (Stevens, 1975 ) to $383 \mathrm{~cm}$ (Bigelow and Schroeder, 1948), though estimates of $L_{\infty}$ (sexes combined) lie between 394 and 423 cm (Aasen, 1966; Stevens, 1975).

Morphometrics: Gubanov (1976) suggested that there were no morphological differences between $P$. glauca from the Indian Ocean and North Atlantic, and data for North Atlantic specimens showed no evidence of stock differentiation in this region (McKenzie and Tibbo, 1964). However, Litvinov (1982) described two separate tooth morphologies of North Atlantic P. glauca, viz subulate and knife-shaped, ascribed to different prey preferences of sharks in oceanic and neritic waters, the former group preferring cephalopods.

Movements and migrations. Over 60000 P. glauca were tagged between 1962 and 1993 under the auspices of the National Marine Fisheries Service, mostly in the
Northwest Atlantic. The recapture rate was 3.8\% and, whilst most reported recaptures were from the US and Canadian waters, large numbers were also recorded from the Grand Banks area, Caribbean Sea, north-eastern coasts of South America and the central Atlantic, north of the equator (Kohler et al., 1998). These data also showed that P. glauca made transatlantic migrations to the waters off western Europe and Northwest Africa. Few individuals were recaptured south of the equator, even though there are important high seas fisheries in these waters, and individuals tagged in the South Atlantic (off Argentina and Uruguay) did not move into the North Atlantic.

In the Eastern Atlantic, some 15000 P. glauca were tagged off Ireland between 1970 and 1998, with a recapture rate of $3.25 \%$ (Fitzmaurice and Green, 2000). Most of the recaptures were from the Azores (77\%), followed by the Canary Islands (13\%), Newfoundland (5.1\%) and Cape Verde (4.4\%). Specimens were also recaptured off the north-eastern United States, Gulf of Mexico, Caribbean and north-eastern South America, but none were reported from southern latitudes. In contrast, Stevens (1976a, 1990) reported than most individuals tagged off south-west England were subsequently recaptured in European waters, though one fish had moved into the South Atlantic.

These results suggest a cyclical movement of P. glauca in the North Atlantic, to the south in the Northeast Atlantic, westwards transatlantic movements from the African coast, and return transatlantic movements from the north-eastern USA and south-east Canada towards the Grand Banks and Northwest Europe (Kohler et al., 1998; Fitzmaurice and Green, 2000).

Parasites and Genetics. Though there are several descriptive studies of parasites associated with $P$. glauca (Adamson et al., 1987; Benz and Dupre, 1987; Curran and Caira, 1995; Rokicki and Bychawska, 1991; Scholz et al., 1998), the results cannot be used to identify stocks. There are no published accounts of the population genetics of P. glauca in the Atlantic Ocean.

Stock identity. Although there are extensive studies on the reproductive biology, growth morphometrics and parasites of blue sharks, these data are insufficient to identify stocks. However, the extensive tagging programmes in the North Atlantic clearly show significant numbers of trans-Atlantic migrations, with few trans-equatorial recaptures and no recaptures from the Indian and Pacific Oceans. Hence, DELASS concluded that the assessment of $P$. glauca should be based on a single North Atlantic stock that is distributed from Venezuela to Canada in the 
west and from Sierra Leone and Ivory Coast to Norway and Iceland in the east, corresponding to FAO Areas 21, 27, 31, 37, 34.

\section{Wide-ranging Small Coastal Shark: Spurdog}

Distribution, population demography and fisheries. Spurdog Squalus acanthias occurs world-wide in temperate and boreal waters. It has been recorded in coastal shelf waters of the Northwest and Northeast Atlantic (including the Mediterranean and Black Seas) and the South Atlantic (Compagno, 1984a).

In the Northeast Atlantic, S. acanthias occurs from 10-200 m depth between Iceland and the northern coasts of Norway and western Russia, and the coast of Northwest Africa (Compagno, 1984b; McEachran and Branstetter, 1989). It is taken in directed fisheries by Norway, Scotland, England and Ireland, and as an important by-catch in trawl fisheries in the Norwegian Sea, Kattegat and Skagerrak, North Sea, Iceland and Faeroe Isles, Northwest Scotland, and English Channel, Irish Sea, west coast of Ireland and Celtic Sea. Landings from adjacent areas are low and, although Squalus spp. are taken in the Bay of Biscay and Cantabrian Sea and off Portugal, these landings could be a mix of $S$. acanthias and $S$. blainvillei.

The use of commercial fishing and survey information showing, for example, spatial differences in the size-frequency of captured fish for examining stock structure, is hampered because $S$. acanthias often aggregate in shoals of the same sex and/or size (Hickling, 1930; Fahy, MS 1988; Fahy, 1989). Whether this segregation is geographi- cal (i.e. males and females inhabit distinct and different areas) or behavioural (i.e. fish of certain sizes and sexes shoal together) is unclear. Nevertheless, shoals with a preponderance of large fish (e.g. mature females) may be targeted by fishermen.

Reproductive biology. S. acanthias is aplacentally viviparous, and Hisaw and Albert (1947), Gilbert and Heath (1972) and Tsang and Callard (1987) give accounts of its reproductive biology and physiology. Size at sexual maturity is relatively well known, although the data shown in Table 2 are not directly comparable as these studies vary in space, time and sampling protocol. Nevertheless, within the Northeast Atlantic, female $S$. acanthias typically start to mature at $69-73 \mathrm{~cm}$, with $50 \%$ of females mature at $74-83 \mathrm{~cm}$. Males mature at a smaller size than females.

Fecundity increases with size, and various methods of estimating fecundity have given quite consistent results for this species. Gauld (MS 1979) recorded maximum fecundity values of 16 (oocytes), 14 (candled embryos) and 13 (free embryos). Estimates of size at birth include $27.5 \mathrm{~cm}$ (Holden and Meadows, 1964) and $26 \mathrm{~cm}$ (range $=19-30 \mathrm{~cm}$; Gauld, 1989) in the Northeast Atlantic.

Growth. Estimates of von Bertalanffy growth parameters for S. acanthias from the Northwest and Northeast Atlantic, using dorsal spine ages, are given in Table 3. However, recent tag returns cast doubt on the use of annuli on the spines, at least for Atlantic specimens, and caution should be used when utilising age data (Martin Vince, pers. comm.). The observed maximum sizes of male and female

TABLE 2. Size-at-maturity of Squalus acanthias.

\begin{tabular}{lcccl}
\hline \hline & \multicolumn{3}{c}{ Length at maturity $(\mathrm{cm})$} & \\
\cline { 2 - 3 } Area & First & $50 \%$ & $100 \%$ & \multicolumn{1}{c}{ Author } \\
\hline Females & & & & \\
NE Atlantic & $60-64$ & - & - & Hickling (1930) \\
& 73 & 82 & 96 & Holden and Meadows (1964) \\
& 71 & 83 & 94 & Gauld (MS 1979) \\
& 69 & $74^{\mathrm{a}}$ & 86 & Fahy (MS 1988, 1989) \\
NW Atlantic & 76 & $77.9^{\mathrm{b}}$ & 86 & Nammack et al., 1985 \\
Black Sea & $97.7-116.3^{\mathrm{c}}$ & - & - & Kirnosova (1989) \\
Males & & & & \\
NE Atlantic & 55 & $59-60$ & 64 & Hickling (1930) \\
NW Atlantic & 58 & $59.5^{\mathrm{e}}$ & 63 & Nammack et al. (1985) \\
\hline a estimated as 14 years & & & \\
b estimated as 12.1 years & & & \\
c estimated as 29 years & & & \\
& & &
\end{tabular}


TABLE 3. Von Bertalanffy growth parameters for Squalus acanthias.

\begin{tabular}{llcccc}
\hline \hline Region & Sex & $L_{\infty}(\mathrm{cm})$ & $K$ & $t_{0}$ (years) & Source \\
\hline Ireland & Male & 79.9 & 0.16 & -1.69 & Fahy (MS 1988, 1989) \\
& Female & 98.8 & 0.19 & -1.57 & \\
British Isles & Male & $79.9(86.0)$ & $0.21(0.14)$ & $-2.0(-3.13)$ & Holden and Meadows $(1962)^{\mathrm{a}}$ \\
& Female & $101.4(104.0)$ & $0.11(0.11)$ & $-3.6(-3.28)$ & \\
North Sea & Male & 81.7 & 0.19 & -1.47 & Sosinski (1977) \\
& Female & 137.1 & 0.05 & -4.71 & \\
& Total & 101.5 & 0.10 & -3049 & \\
NW Atlantic & Male & 82.49 & 0.148 & -2.67 & Nammack et al. (1985) \\
& Female & 100.5 & 0.1067 & -2.90 & \\
\hline
\end{tabular}

a Original data and recalculated values (as given by Fahy (1989)) in parentheses.

S. acanthias (reviewed by Ketchen, 1972) where 83-86 and $108-110 \mathrm{~cm}$, respectively, for the North Atlantic.

Morphometrics. Morphological studies of S. acanthias have found differences in certain body dimensions (e.g. fin lengths) between Pacific and Atlantic specimens. Springer and Garrick (1964) gave preliminary data on the number of precaudal vertebrae counts ranging from 68-76 (North Pacific), 75-78 (southern hemisphere) and 79-95 (North Atlantic). There are, however, insufficient data to compare the body dimensions, vertebral counts and dental formulae of $S$. acanthias within the North Atlantic.

Parasites and genetics. Although several studies have discussed the parasites of $S$. acanthias, there are no specific studies examining the use of parasites in stock identity. Neither are there any published studies on population genetics of $S$. acanthias.

Movements and migrations. Published information on S. acanthias migrations based on British and Norwegian tagging studies (Holden, 1967a; Aasen, 1960; Aasen, 1962) indicated little mixing between northern waters and southern areas, and Scottish-Norwegian and Channel stocks were claimed by Holden (1965, 1967b, 1968). Most fish, however, were returned from Scottish and Norwegian waters, where the major fisheries occurred, and the proportionately fewer returns from outside this area may have been due to spatial differences in fishing activity at the time of these studies. More recent tagging exercises in southerly areas have shown movement from the north-western Irish Sea to northern Scotland and the Celtic Sea and from the Celtic Sea all around the British Isles (Vince, 1991). Hjertenes (MS 1980) also reported that migration patterns of S. acanthias in the North Sea had changed, and they were more frequently caught in the southern North Sea. Though trans-Atlantic migrations have been reported (Templeman, 1954, 1976, 1984), they are rare, and the most recent analyses of tagging studies have indicated that Northeast and Northwest Atlantic stocks should be treated independently.

Stock identity. In the Northeast Atlantic, S. acanthias is most abundant in the shelf waters north of the Bay of Biscay to the coast of Norway. There are major differences in the species' life-history parameters between the Pacific and Atlantic populations, but studies of Atlantic populations differ in methodology and/or the time period of data collection and cannot be used to separate stocks. There is little or no data regarding morphometrics/meristics, parasites or genetics for $S$. acanthias, hence, evidence of stock identity is based largely on the interpretation of distribution patterns and tagging studies, which indicate a single Northeast Atlantic stock. DELASS therefore concluded that the assessment of $S$. acanthias should be based on a single stock extending from the Norwegian Sea to the northern Bay of Biscay, which includes ICES Divisions IIa, IIIa, and VIIIa,b and Sub-areas IV, V, VI and VII.

\section{Coastal Skate: Thornback Ray}

Distribution, population demography and fisheries. Raja clavata occurs in coastal waters of the Northeast Atlantic from the Faroe Islands, Iceland and Norway in the north to north-western Africa, including the Skagerrak, Kattegat and western Baltic Sea, and the Mediterranean and Black Seas (Stehmann and Bürkel, 1989). It is found on the shelf and upper slope from inshore to depths of $300 \mathrm{~m}$, but occurs mainly from 10-60 m (Stehmann and Bürkel, 1989; Fahy and O'Reilly, 1990). Juveniles are most often encountered in inshore waters (Rousset, 1990; Ellis et al., 2004). The spatial range of $R$. clavata in the North Sea decreased from 1979 to 1993 and, whereas it was formerly distributed over the entire south-western, central and northern North Sea, it is now caught predominantly off the coasts of England and Scotland (Walker et al., 1997). 
Although $R$. clavata is one of the dominant skate species taken in European fisheries, most commercial landings data are for "skates and rays" combined. Data by species are available for France, but these do not allow the proportion of $R$. clavata in commercial landings to be adequately estimated. Species compositions in research vessel surveys and historical accounts indicate that $R$. clavata is one of the most abundant rays in the southwestern North Sea, eastern English Channel, Bristol Channel and Irish Sea (Steven, 1932, 1933; Ellis et al., 2004).

Reproductive biology. R. clavata is oviparous, and the egg-laying season for the population as a whole is protracted (Capapé, 1976; Ryland and Ajayi, 1984). Both the number and the maximum diameter of oocytes increase with increasing body size (Walker, 1998 to 1999). Estimates of annual egg production range from 62-74 (west Wales: Ryland and Ajayi, 1984) to 140-150 (England and Wales: Holden et al., 1971; Holden, 1975) and 141-167 eggs/year (Tunisia: Capapé, 1976), though captive $R$. clavata generally lay $<50$ eggs per year (Ellis and Shackley, 1995a).

Though there are a number of estimates of the embryonic developmental period (4-6 months), length of young at hatching $\left(11-13 \mathrm{~cm} L_{T}\right)$ and sex ratio (not significantly different from 1:1), these parameters appear relatively consistent (Clark, 1922, 1926; Capapé, 1976; Ellis and Shackley, 1995a; Holden et al., 1971; Steven, 1933).

A summary of information on the size at maturity around the British Isles and in the Mediterranean is given in Table 4.

Growth. Most age studies of rays rely heavily on back calculation and growth modelling, though tagging seems to be most suitable for verification (Walker and Heessen, 1996). There are several published estimates for the von Bertalanffy equation (e.g. Holden, 1972; Ryland and Ajayi, 1984; Fahy, 1989; Walker, 1998 to 1999), but differences in sampling protocol and year of sampling restrict spatial comparisons. Furthermore, estimates of the length range of 0-group $R$. clavata are inconsistent (Brander and Palmer, 1985), presumably because of difficulties in age determination, though it is unclear what affect this may have had on older age-classes.

Morphometrics. Although there are some basic accounts of the morphology and meristics for R. clavata from around the British Isles (Clark, 1926) and the Adriatic Sea (Jardas, 1975), there are no comparative studies of spatial variation in $R$. clavata morphology in the Northeast Atlantic.

Movements and Migrations. Steven (1932, 1936) reported only $11 \%$ of recaptured tagged $R$. clavata having moved more than $32 \mathrm{~km}$ from the release point off Plymouth (VIIe), and concluded that they migrate into shallower water during summer, and move offshore locally in the winter, whilst juveniles are non-migratory and remained on inshore nursery grounds. This pattern of movement was supported by Walker et al. (1997) analysis of tagging records (from Holden, 1972), which showed that there was very little exchange of individuals between the eastern English Channel and the North Sea, and suggest that these areas contain separate stocks. Walker et al. (1997) suggested that the $R$. clavata stock in the North Sea could be seen as a series of local concentrations with regular exchange of individuals, although the majority of rays moved no further than $50-60 \mathrm{~km}$ from the release site over a period of several years. The Thames Estuary seems to be an important centre for the North Sea stock of $R$. clavata.

Parasites and population genetics. Although there are some descriptive accounts of the parasites of $R$. clavata (Kabata, 1979), there are no studies which can be used to identify stocks. There are no accounts of population genetics, but Blake (1976) examined the eye lens proteins from four locations around the Irish Sea and reported that there was no evidence for separate stocks.

Stock identity. Although R. clavata is one of the most abundant rays in Northwest Europe, it is not possible to

TABLE 4. Size $\left(L_{T} \mathrm{~cm}\right)$ at maturity of Raja clavata.

\begin{tabular}{lccl}
\hline \multicolumn{1}{c}{ Sea area } & Male & Female & \multicolumn{1}{c}{ Source } \\
\hline Plymouth (VIIe) & $74-81$ & $96-101$ & Steven (1934) \\
Western Ireland (VIIb,c) & $55-62$ & $66-73$ & Fitzmaurice (1974) \\
Bristol Channel (VIIf) & 60.5 & 59.5 & Ryland and Ajayi (1984) \\
Solway Firth (VIIa) & 62 & 65 & Nottage and Perkins (1983) \\
North Sea (IVc) & 68 & 77 & Walker (1998) \\
Mediterranean Sea & 75 & 85 & Capapé (1976) \\
Adriatic Sea & 54 & 73 & Jardas (1973) \\
\hline
\end{tabular}


estimate the proportion of this species in the total 'mixed skates and rays' landings. There is insufficient information on morphology, population genetics or parasites to identify stocks of $R$. clavata and, though data from life-history parameters are available, these studies differ in the time and method of data collection, thus preventing accurate analysis of spatial variation. Hence, the determination of stock identity for $R$. clavata in the Northeast Atlantic is based primarily on the interpretation of distribution patterns and tagging studies. These have indicated limited movements, and suggest that the $R$. clavata population in the North Sea is largely restricted to the southern and central North Sea, and shows little mixing with the English Channel population. DELASS therefore concluded that IVb, c was an appropriate assessment area for $R$. clavata.

\section{Small-bodied Oviparous Sharks: Lesser-spotted Dogfish}

Distribution, population demography and fisheries. Lesser spotted dogfish Scyliorhinus canicula is a common demersal shark on the continental shelf of the Northeast Atlantic, which occurs from the Shetland Islands and southern Norway to north-western Africa as far south as Senegal (Blache et al., 1970), including the Mediterranean and Adriatic Seas.

Commercial catch and research vessel survey data indicate that $S$. canicula is widespread and abundant in the Irish Sea, English Channel, Bristol Channel, southern and western coasts of Ireland, Bay of Biscay and Portuguese waters. It also occurs in the North Sea and Northwest Scotland, although it is less abundant in these areas (Quero et al., 1989; Knijn, et al., 1993; Figueiredo et al., 1995; Sánchez et al., 1995; Ellis et al., 2004). In the north of its range, it is most common at depths down to $110 \mathrm{~m}$ (Wheeler, 1978; Compagno, 1984a), whilst in the Cantabrian Sea most fish are caught in water 150-300 m deep (Sánchez, 1993). Whereas the adult population appears to be continuous along the continental shelf, there is evidence of spatial segregation, with fish of certain sizes and sexes shoaling together (e.g. Ford, 1921).

Scyliorhinus canicula is seldom commercially exploited within the Northeast Atlantic, and a high proportion of the catch is discarded $(>80 \%)$, many of which survive (Fernandez et al., MS 2001). Typically, only specimens $>46 \mathrm{~cm} L_{T}$ are retained. Accurate national landings data are not usually available, as they are recorded as "dogfish and hounds". However, Spanish data on by-catches are available from Sub-areas VI, VII and VIII, and Division IXa. Some data are also available from France and Portugal. The only useful CPUE data are from VIIIc for Spain.
Reproductive biology. S. canicula is oviparous and deposits egg-cases protected by a horny capsule with long tendrils (Wheeler, 1978). Moreno (1995) suggested that females and males move to the breeding areas in winter and summer respectively, with mating occurring during the summer.

The size at sexual maturity is relatively well known, but the data given in Table 5 are not directly comparable, as most studies vary in time of sampling, though there is a general tendency for the size at first maturity to be related with latitude (Lam, 1983; Leloup and Olivereau, 1951; Capapé et al., 1991). Within the Northeast Atlantic, female $S$. canicula typically begin to mature at $49-52 \mathrm{~cm}$ $L_{T}$, with $50 \%$ of females mature at $54-60 \mathrm{~cm} L_{T}$. Males tend to mature at a slightly smaller size than females.

Fecundity increases with maternal size, and estimates of annual fecundity vary: 29-62 eggs/year in the Bristol Channel (Ellis and Shackley, 1997); 45-190 in the French Mediterranean (Capapé et al., 1991) and 96-115 off Tunisia (Capapé, 1977).

Spawning takes place through most of the year (Table 6), and development lasts approximately 8-9 months, depending on temperature (Ellis and Shackley, 1997). Length at birth lies within the range 9-11 cm $L_{T}$ (Ford, 1921, Collenot, 1966; Mellinger and Wrisez, 1984; Ellis and Shackley, 1997). Little is known about spawning areas, and though English surveys rarely catch juveniles, in the Cantabrian Sea they are found mostly in the eastern part, in deeper waters than adults, and they also occur in colder water.

Morphometrics. Morphometric studies have shown that Atlantic S. canicula may be up to $30 \%$ longer and $50 \%$ heavier than their congeners from the Mediterranean (Borcea, 1907; Belloc, 1929; Leloup and Olivereau, 1951). Estimates for the von Bertalanffy growth parameters and observed maximum lengths are given in Table 7 . There are other differences between these populations in embryonic and adult morphology (e.g. Bas, 1964; Mellinger and Wrisez, 1984; Muñoz-Chapuli, 1984). Furthermore, ontogenetic and sexual dimorphism in several body dimensions also occurs (Ellis and Shackley, 1995b), and could be considered if sufficient data become available to examine geographical variation in body morphology. Dental formulae for $S$. canicula are highly variable within a population, and such data should be used with caution.

Movements and migrations. Tagging studies in the Cantabrian Sea (VIIIc) have shown individual S. canicula 
TABLE 5. Size-at-maturity of female and male Scyliorhinus canicula.

\begin{tabular}{lccl}
\hline \hline \multicolumn{1}{c}{ Area } & Male & Female & \multicolumn{1}{c}{ Source } \\
\hline Atlantic & & & \\
Atlantic & $52-60$ & $52-60$ & Faure-Fremiet (1942) \\
Atlantic & $52-60$ & $52-60$ & Leloup and Olivereau (1951) \\
English Channel & $57-60$ & $57-60$ & Ford (1921) \\
English Channel & $60-68$ & $60-68$ & Collenot (1966) \\
Bristol Channel & $49-54$ & $52-64$ & Ellis and Shackley (1997) \\
Ireland & $53-61$ & $52-64$ & Henderson and Casey (2001) \\
Bay of Biscay & - & $49-57$ & Rodriguez-Caballo et al. (1998) \\
Gulf of Cadiz & $46-50$ & $46-50$ & Munoz-Chapuli et al. (1984) \\
& & & \\
Mediterranean & & & \\
France & $37-44$ & $37-44$ & Leloup and Olivereau (1951) \\
France & 44 & $41-47$ & Capape et al. (1991) \\
Alboran Sea & $38.5-42$ & $38.5-42$ & Munoz-Chapuli et al. (1984) \\
Tunisia & 40 & $40-45$ & Capape (1977) \\
Adriatic Sea & 34 & 34 & Zupanovic (1961) \\
Adriatic Sea & $27-33$ & $31-40$ & Jardas (1979) \\
\hline
\end{tabular}

TABLE 6. Egg-laying season and length at birth (mm) for Scyliorhinus canicula.

\begin{tabular}{|c|c|c|c|c|c|}
\hline Area & $\begin{array}{l}\text { All } \\
\text { Year }\end{array}$ & Peak & Low & Length & Source \\
\hline \multicolumn{6}{|l|}{ Atlantic } \\
\hline Irish Sea & $\times$ & Spr/Win & Sum & & Sumpter and Dodd (1979) \\
\hline Bristol Channel & $x$ & Jan-Jul & Sep-Oct & & Harris (1952) \\
\hline Bristol Channel & $\times$ & Jun-Jul & Aug-Sep & $90-112$ & Ellis and Shackley (1997) \\
\hline English Channel & $x$ & Aug & Sept-Oct & $90-100$ & Ford (1921) \\
\hline Roscoff & $\times$ & & & $90-100$ & Leloup and Olivereau (1951) \\
\hline Roscoff & $\times$ & & & $95-115$ & Collenot (1966) \\
\hline Concarneau & $x$ & & & & Faure-Fremiet (1942) \\
\hline Atlantic/Med. & $\times$ & & Aut & $90-100$ & Mellinger and Wrisez (1984) \\
\hline \multicolumn{6}{|l|}{ Mediterranean } \\
\hline France & $\times$ & & & $80-90$ & Leloup and Olivereau (1951) \\
\hline France & $x$ & Spr/Win & Sum/Aut & $84-88$ & Capapé et al. (1991) \\
\hline
\end{tabular}

that have moved up to $286 \mathrm{~km}$, but the majority do not appear to move further than $30 \mathrm{~km}$, and $70 \%$ of recaptured fish were caught less than 15 miles from the release position (Rodriguez-Cabello et al., 1997, MS 2001). This supports the hypothesis that this species does not make long migrations.

Parasites, contaminants and population genetics. S. canicula is known to be parasitised by a variety of species (Jardas, 1979; Sanmartin et al., 1989;
Caira, 1990; Quintero, 1990). Moore (2001) discussed the use of parasites for identifying stocks of $S$. canicula and, although sample sizes were limited and the work preliminary, there were some differences in the parasitic fauna (e.g. the range of species and prevalence of larval anisakid nematodes) between samples from Cardigan Bay (VIIa), Plymouth (VIIe) and the Solent (VIId). A preliminary analysis of mercury concentrations in $S$. canicula from the Irish Sea (Leah et al., 1991a, 1991b) indicated some spatial differences, which may be related to separate 
TABLE 7. Von Bertalanffy growth parameters and maximum length of Scyliorhinus canicula.

\begin{tabular}{lccccl}
\hline \hline & & \multicolumn{5}{c}{$L_{\text {max }}$ observed } \\
Area & $L_{\infty}$ & $K$ & Male & Female & \multicolumn{1}{c}{ Source } \\
\hline Atlantic & & & & & \\
$\quad$ North Sea & 88.0 & 0.20 & & & Jennings et al. (1999) \\
Ireland & 82.7 & 0.15 & & & Henderson and Casey (2001) \\
Bristol Channel & & & 66 & 67 & Ellis and Shackley (1997) \\
English Channel & & & 70 & 70 & Ford (1921) \\
Roscoff & & & 66 & 66 & Faure-Fremiet (1942) \\
Concarneau & & & 72 & 72 & Faure-Fremiet (1942) \\
Atlantic & & & 68 & 68 & Leloup and Olivereau (1951) \\
Bay of Biscay & 88.8 & 0.13 & & & Rodriguez-Cabello et al. (1998) \\
Mediterranean & & & & & \\
France & & & 48.5 & 48.5 & Leloup and Olivereau (1951) \\
France & & & 55 & 51 & Capape et al. (1991) \\
Adriatic Sea & 56.8 & 0.53 & & & Zupanovic (1961) \\
\hline
\end{tabular}

populations. There are no published studies on population genetics of $S$. canicula.

Stock identity. Studies on body morphology and meristics in Scyliorhinus canicula have focused on differentiating Atlantic and Mediterranean stocks, and there are insufficient comparable data within Atlantic populations. The few studies on life-history parameters suggest that specimens from UK waters grow larger than in Spanish Atlantic waters. Tagging studies indicate limited geographical movements, and suggest that they form localised populations. The limited accounts of spatial differences in parasites and metal concentrations also imply that $S$. canicula occur in localised populations. DELASS concluded that $S$. canicula populations would best be assessed as local populations (e.g. on the level of an ICES Division), with insignificant immigration and emigration from adjacent populations, and that due to the availability of fisheries statistics and biological data, assessing this species within the Cantabrian Sea (VIIIc) was appropriate.

\section{Deep-water Sharks: Leafscale Gulper Shark and Portuguese Dogfish}

Distribution, population demography and fisheries. Leafscale gulper shark Centrophorus squamosus is found in the eastern Atlantic (from Iceland to Senegal and off Namibia and South Africa), whilst Portuguese dogfish Centroscymnus coelolepis is found in the Northwest Atlantic (from the Grand Banks to off Delaware Bay, and Cuba), eastern Atlantic (from Iceland to Sierra Leone, including the western Mediterranean, and from Namibia to South Africa) (Compagno, 1984a).
Based on commercial landings and research vessel surveys, the distributions of $C$. squamosus and C. coelolepis in the Northeast Atlantic are similar, though the latter species is also found off Norway, the Faeroes Islands and off Madeira. Recorded depth ranges in the Northeast Atlantic are given in Table 8 . Both species are mainly recorded from depths of 600-1 $500 \mathrm{~m}$ throughout their range, though $C$. squamosus may occur $<500 \mathrm{~m}$, whilst C. coelolepis is more often recorded in water $>1900 \mathrm{~m}$.

Centrophorus squamosus and C. coelolepis are exploited in various deep-water fisheries in the Northeast Atlantic. They are taken in a French multi-species trawl fishery along the shelf edge in Biscay and to the west of the British Isles, where Irish fisheries also use longlines. France reports combined landings of these two species as 'siki', thus the proportion of each species in commercial landings is not known. Landings from Portuguese and Azores fisheries are, however, species-specific. Centroscymnus coelolepis is the main by-catch in a Norwegian fishery for Greenland halibut (Reinhardtius hippoglossoides) started recently on Hatton Bank (N.-R. Hareide, Ulsteinvik, Norway, pers. comm.).

Length composition data from experimental fishing and surveys show that small specimens of $C$. squamosus ( $<80 \mathrm{~cm}$ length) were not recorded from west of the British Isles and at Hatton Bank, whereas fish $<60 \mathrm{~cm}$ length are caught off Portugal (Girard, 2000). Furthermore, males and immature females are more common on the grounds to the west of the British Isles, whereas females (including pregnant fish) are more frequent in samples off Portugal. 
TABLE 8. Depths at which C. squamosus and C. coelolepis have been reported from commercial fishing and research surveys in the Northeast Atlantic.

\begin{tabular}{lrrl}
\hline \hline Sea area & C. squamosus & C. coelolepis & \multicolumn{1}{c}{ Source } \\
\hline Iceland & $933 \mathrm{~m}$ & $1169 \mathrm{~m}$ & Magnússon et al. (2000) \\
Reykjanes Ridge, west of Norway & $1400-1900 \mathrm{~m}$ & $1400-1900 \mathrm{~m}$ & Hareide and Garnes (2001) \\
Hatton Bank & $600-1200 \mathrm{~m}$ & $600-1200 \mathrm{~m}$ & Muñoz et al. (2001) \\
Rockall Trough & $458-1019 \mathrm{~m}$ & $667-1750 \mathrm{~m}$ & Gordon (1999) \\
west of Ireland & $600-1400 \mathrm{~m}$ & & Girard (2000) \\
Porcupine Seabight & $750-1500 \mathrm{~m}$ & $750-2050 \mathrm{~m}$ & Merret et al. (1991) \\
off Portugal & $800-1500 \mathrm{~m}$ & $800-1500 \mathrm{~m}$ & Veríssimo et al. (2003) \\
\hline
\end{tabular}

The length composition of $C$. coelolepis is similar in several areas of the Northeast Atlantic, although smaller specimens (total length $<70 \mathrm{~cm}$ ) are found regularly off Portugal. Girard (2000) reported significant differences between length frequencies in three distinct areas west of the British Isles, though this could represent spatial segregation of different size/sex-classes rather than distinct stocks.

Reproductive biology. Both species are ovoviviparous. Data on size at maturity, fecundity and gestation for C. squamosus and C. coelolepis are available from Icelandic waters, west of the British Isles and off the Portuguese mainland (Magnússon et al., 2000; Girard, 2000; Clarke et al., 2002; Veríssimo et al., 2003). However, the different characteristics of the fisheries taking these species in the Northeast Atlantic make the comparison between biological data difficult for the evaluation and identification of stocks.

Fecundity estimates are available for C. coelolepis from two areas, west of the British Isles and off Portugal, with uterine (number of embryos developing) fecundity being 13 and 10, respectively, whilst ovarian fecundity (number of oocytes in the ovary) is 13 in both areas, (Clarke et al., 2002; Veríssimo et al., 2003). It is unlikely that these minor differences indicate separate stocks.

Growth and morphometrics. There are no published studies on age or growth of either species and, although basic morphological descriptions are available, these data are insufficient for use in the identification of stocks. However, different colour-morphs of C. squamosus have been recorded at Hatton Bank, where around two-thirds of adult individuals are black, and off Portugal and around Madeira, where a brown type predominates. These could indicate different stocks.

Parasites and genetics. There is little information regarding the parasites of C. squamosus or C. coelolepis, and there are no published studies on population genetics.
Movements and migrations. There is a lack of knowledge on migrations (Girard, 2000), though it is thought that female $C$. coelolepis move to shallower waters for parturition and vertical migration may occur (Clarke et al., 2001). Evidence from fishing records suggests that both species may be highly migratory.

Stock identity. DELASS concluded that the biological data available were insufficient to ascertain the stock structure of C. squamosus or C. coelolepis within the Northeast Atlantic and, in the absence of any evidence of stock separation, it was assumed that the preliminary assessment should focus on a single stock of each species. As much of the landings data from the west of the British Isles are combined (as "siki"), a joint assessment of C. squamosus-C. coelolepis may have some benefits. Given the increasing fishing pressure on these species, further studies are warranted. Because fishery-independent surveys are unlikely to be undertaken in the near future, and tagging studies are not practical, the use of population genetics and parasites offer the greatest promise for determining stock identity in deep-water squaliform sharks.

\section{Conclusions and Recommendations}

1) There have been considerable changes in the exploitation of elasmobranchs in the last two decades but, for most species, research programmes have not yet been developed that enable sound management proposals to be made in relation to biologically meaningful stock units. It appears that fisheries scientists, at least in the short term, need to take a flexible approach to elasmobranch stock identification if preliminary assessments are to be undertaken and advice given on management strategies.

2) Although characteristics such as maturity ogives, length-weight conversion factors, morphometrics and meristics may have a role in classical studies of teleost stock identity, the natural variability in such 
characters and the difficulty in obtaining suitable sample sizes for the various life-history stages over an appropriate geographical scale for elasmobranch fishes suggest that they are not good indicators of stock separation if used in isolation. Parasitological approaches appear to offer more promise, particularly if used in conjunction with other methods, although more information on the taxonomy, life-history and biogeography of parasites of elasmobranch species is required.

3) Ideally, an appropriate method for stock identification would allow individuals sampled from commercial landings to be assigned to specific stocks. Although molecular techniques may be able to differentiate between different stocks, elasmobranchs may not be the target species and may be discarded or processed at sea, and it is unlikely that market samples can be attributed to specific biological stocks or management units. As a consequence, the practical use of genetic markers may be limited, other than in the monitoring of trade (e.g. shark fins) and identification of protected species (e.g. those species listed under CITES).

4) Information on population demography (age/length structure, spatial distribution of various life stages) does enable us to recognise the relationships between fisheries and resource, and to point out where sampling should take place. Although such data are typically available for coastal demersal elasmobranchs, the absence of internationally-co-ordinated, fisheryindependent surveys for pelagic and deep-water sharks restricts data availability for many important fishery species.

5) Tagging studies have provided the best evidence for stock migrations and separation, but they have targeted comparatively few elasmobranch species and most were not designed to explore population/stock structure on an appropriate spatial scale. Whereas data for the more abundant commercial and/or recreational sharks (e.g. blue shark and spurdog) are relatively robust, data for less abundant species may be lacking. More carefully planned tagging programmes are required to better establish the relationships between fish in adjacent regions.

6) Integrated studies that incorporate the results from tagging experiments are most likely to produce working hypotheses on stock identity that can be tested with other techniques (e.g. genetics, parasites) and, once validated, can be adopted and used by fishery managers. Tagging studies may also provide valuable information for age validation, growth determination and longevity, subjects which are an important component in stock identification and management.

7) Whereas traditional tagging programmes will indicate the main range and migrations of a species, and identify which fisheries are involved in exploitation of the stock, there is also the need to understand fine-scale movements between breeding, spawning, nursery and feeding areas, and whether a species is local in its movement. Hence, the use of archival tags is a priority. The use of such tags, including pop-up tags, should also be investigated for those data-poor species for which conventional tags have not provided sufficient information.

8) Studies on the distribution and movements of elasmobranchs should also examine the environmental parameters that are associated with the species' distribution (e.g. habitat and hydrographic data), and that may be used to show likely boundaries of movement. Such data would further the application of Geographical Information Systems (GIS) in the management of elasmobranch stocks.

9) Undoubtedly, a comprehensive understanding of their life-history is an important element in the successful identification and management of elasmobranch stocks. Similarly, information on the various lifehistory stages (e.g. egg-cases of oviparous species, gravid females and juveniles in nursery areas) from surveys and commercial landings will aid interpretations of distribution, movements and, ultimately, the identity of the component stocks.

10) A high-quality description of the various fisheries exploiting the stock is essential, not just to help with stock identity, but to plan any biological sampling programmes with which appropriate data can be collected for the assessment of stocks in relation to exploitation and biological sustainability.

\section{Acknowledgements}

We thank our colleagues in the DELASS project for their input, and colleagues at CEFAS and an anonymous referee for useful comments on the manuscript. This work was part funded by the EU under the DELASS project (CFP 99/055) and the UK's Department of Environment, Food and Rural Affairs (Defra). 


\section{References}

AASEN, O. 1960. Norwegian dogfish tagging. Ann. Biol. (Cph), (1958) 15: 76.

1962. Norwegian dogfish tagging. Ann. Biol. (Cph), (1960) 17: 106-107.

1966. Blahaien, Prionace glauca (Linnaeus). 1758. Fisken og Havet, 1: 1-10.

ADAMSON, M. L., G. B. DEETS, and G. W. BENZ. 1987. Description of male and redescription of female Phlyctainophora squali Mudry and Dailey, 1969 (Nematoda; Dracunculoidea) from elasmobranchs. Can. J. Zool., 65(12): 3006-3010.

ANON. 2003. Development of Elasmobranch Assessments, DELASS. DG Fish Study Contract 99/055: 708 p.

BACKUS, R. H. 1957. Notes on western North Atlantic sharks. Copeia, 1957(3): 246-248.

BAS, C. 1964. Aspectos del crecimiento relativo de Scyliorhinus canicula. Investig. Pesq., 27: 3-12.

BELLOC, G. 1929. Poissons de chalut. Etude monographique du Merlu. (Merluccius merluccius L.) $2^{\circ}$ partie. Rev. Trav. Off. Pêches, 2: 231-288.

BENZ, G. W., and K. S. DUPRE. 1987. Spatial distribution of the parasite Kroyeria carchariaeglauci Hesse, 1979 (Copepoda: Siphonostomatoida: Kroyeriidae) on gills of the blue shark (Prionace glauca (L., 1758)). Can. J. Zool., 65(5): 1275-1281.

BEVERTON, R. J. H., and B. C. BEDFORD. 1963. The effect on the return rate of condition of fish when tagged. ICNAF Spec. Publ., 4: 106-116.

BIGELOW, H. B., and W. C. SCHROEDER. 1948. Sharks. In: Fishes of the Western North Atlantic Part One. Memoir one, Sears Foundation for Marine Research, Yale University, $576 \mathrm{p}$.

BLACHE, J., J. CADENAT, and A. STAUCH. 1970. Clés de détermination des poissons de mer signalés dans 1' átlantique oriental. Faune Tropicale ORSTOM, Paris, 18: $479 \mathrm{p}$.

BLAKE, B. 1976. Polymorphic forms of eye lens protein in the ray Raja clavata (Linnaeus). Comp. Biochem. Physiol., 54B: 441-442.

BRANDER, K., and D. PALMER. 1985. Growth rate of Raja clavata in the Northeast Irish Sea. J. Cons. Int. Explor. Mer, 42: 124-128.

BORCEA, I. 1907. Observations sur quelques Raies de la baie de Naples. Ann. Sci. Univ. Jassy, 4: 180-186.

BOUSTANY, A. M., S. F. DAVIS, P. PYLE, S. D. ANDERSON, B. J. LE BOEUF, and B. A. BLOCK. 2002. Satellite tagging: expanded niche for white sharks. Nature, 412(6867): 35-36.

BUCKLEY, A. A., and J. D. METCALFE. 2002. The movement and behaviour of thornback ray, Raja clavata, in the Thames Estuary. Proceedings of the $4^{\text {th }}$ Meeting of the European Elasmobranch Association, 191.

CAIRA, J. N. 1990. Metazoan parasites as indicators of elasmobranch biology. In: Elasmobranchs as living resources: Advances in the biology, ecology, systematics, and the status of the fisheries. H. L. Pratt, S. H. Gruber and T. Taniuchi (eds.). U.S. Dept. Comm., NOAA Tech. Rep.,
No. NMFS 90: 71-96.

CAPAPÉ, C. 1976. Contribution à la biologie des Rajidae des côtes tunisiennes III. Raja clavata Linné, 1758: Répartition géographique et bathymétrique, sexualité, reproduction et fécondite. Bull. Mus. Nat. d'Hist. Natur., 3e Ser., No. 393: 907-922.

1977. Contribution a la biologie des Scyliorhinidae des côtes tunisiennes S. canicula (L. 1978). Repartition gèographique et bathymètrique, sexualite, reproduction, fècondité. Bull. Off. Natn. Pêche. Tunisie, 1: 83-101.

CAPAPÉ, C., J. A. TOMASINI, and J. L. BOUCHEREAU. 1991. Observations sur la biologie de la reproduction de la petite roussette Scyliorhinus canicula (L. 1758) (Pisces, Scyliorhinidae) du Golfedu Lion (France Meridiona). Ichtyophysiol. Acta, 14: 87-109.

CAREY, F. G., and J. V. SCHAROLD. 1990. Movements of blue sharks (Prionace glauca) in depth and course. Mar. Biol., 106(3): 329-342.

CARVALHO, G. R., and L. HAUSER. 1994. Molecular genetics and the stock concept in fisheries. Rev. Fish. Biol. Fish., 4(3): $326-350$.

CASTRO, J. A., and J. MEJUTO. 1995. Reproductive parameters of the blue shark, Prionace glauca, and other sharks in the Gulf of Guinea. Mar. Freshw. Res., 46: 967-973.

CLARK, R. S. 1922. Rays and Skates (Raiae) No. I: Egg capsules and young. J. Mar. Biol. Assoc. U.K., 12: 577-643.

1926. Rays and skates. A revision of the European species. Fish. Bd. Scotland, Sci. Investiga., 1: 1-66.

CLARKE, M. W., P. L. Connolly, and J. J. Bracken. 2001. Aspects of reproduction of the deepwater sharks Centroscymnus coelolepis and Centrophorus squamosus from west of Ireland and Scotland. J. Mar. Biol. Ass. U.K., 81: 10191029.

CLARKE, M. W., P. L. CONNOLLY, and J. J. BRACKEN. 2002. Age estimation of the exploited deepwater shark Centrophorus squamosus from the continental slopes of the Rockall Trough and Porcupine Bank. J. Fish Biol., 60: $501-514$.

COLLENOT, G. 1966. Observations relatives au developpement au laboratoire d'embryons et d'individus juveniles de Scyliorhinus canicula L. Cah. Biol. Mar., 7: 319-330.

COMPAGNO, L. J. V. 1984a. FAO species catalogue. Vol. 4. Sharks of the world. An annotated and illustrated catalogue of shark species known to date. Part 1. Hexanchiformes to Lamniformes. FAO Fish. Synop., 125(1): 1-249.

1984b. FAO species catalogue. Vol. 4. Sharks of the World: an annotated and illustrated catalogue of shark species known to date. Part 2: Carcharhiniformes. FAO Fish. Synop., 125(2): 251-655.

CRUMMEY, C., M. RONAN, and E. FAHY. 1991. Blue shark Prionace glauca (L.) in Irish waters. Ir. Nat. J., 23(11): 454-456.

CURRAN, S., and J. N. CAIRA. 1995. Attachment site specificity and the tapeworm assemblage in the spiral intestine of the blue shark (Prionace glauca). J. Parasitol., 81(2): 149-157.

DRAGANIK, B., and W. PELCZARSKI. 1984. The occurrence of the blue shark, Prionace glauca (L.), in the North Atlantic. Prace Morski Instytut Rybacki w Gdynia (Report 
of the Sea Fisheries Institute, Gdynia), 19: 61-75.

DUTIL, J-D, B. LEGARE, and C. DESJARDINS. 1985. Discrimination d'un stock de poisson, l'anguille (Anguilla rostrata), basee sur la presence d'un produit chimique de synthese, le mirex. Can. J. Fish. Aquat. Sci., 42: 455-458.

ELLIS, J. R., A. CRUZ-MARTINEZ, B. D. RACKHAM, and S. I. ROGERS. 2004. The distribution of chondrichthyan fishes around the British Isles and implications for conservation. J. Northw. Atl. Sci., 35: 195-213 (this volume).

ELLIS, J. R., and S. E. SHACKLEY. 1995a Observations on egg laying in the thornback ray, Raja clavata. J. Fish Biol., 46: 903-904.

1995b. Ontogenic changes and sexual dimorphism in the head, mouth and teeth of the lesser spotted dogfish. J. Fish Biol., 47: 155-164.

1997. The reproductive biology of Scyliorhinus canicula in the Bristol Channel, U.K. J. Fish Biol., 51: 361-372.

FAHY, E. MS 1988. Recent developments in the Irish fisheries for spurdog, Squalus acanthias (L.). ICES C.M. Doc., No. 1988/H:6, 12 p.

1989. The spurdog Squalus acanthias (L.) fishery in south-west Ireland. Irish Fish. Investig. Series B (Mar.), 32, $22 \mathrm{p}$.

FAHY, E. and O'REILLY, R. 1990. Distribution patterns of rays (Rajidae, batoidei) in Irish waters. Ir. Nat. J., 23(8): 316-320.

FAURE-FREMIET, E. 1942. Notes sur la biologie sexuelle de S. canicula. Bull. Biol. Fr. Belg., 76: 244-249.

FERNANDEZ, A, C. RODRIGUEZ-CABELLO, I. OLASO, and F. SANCHEZ. MS 2001. Survival of lesser spotted dogfish (Scyliorhinus canicula, L.) discarded by trawlers. ICES C.M. Doc., No. 2001/N:06.

FIGUEIREDO, I., M. J. FIGUEIREDO, and O. MOURA. 1995. Distribution, abundance and size composition of blackmouth catshark (Galeus melastomus) and small spotted dogfish (Scyliorhinus canicula) on the slope of the Portuguese South and Southwestern coast. ICES C.M. 1995/G:9, 38 p.

FITZMAURICE, P. 1974. Size distribution and food of Thornback rays (Raja clavata L.) caught on rod and line on the Mayo coast. Ir. Fish. Investig. Series B, 11: 18 p.

FITZMAURICE, P., and P. GREEN. 2000. Results from tagging of blue shark in Irish waters. Ir. Scientist Yearbook, 3: $51 \mathrm{p}$.

FORD, E. 1921. A contribution to our knowledge of the life histories of the dogfishes landed at Plymouth. J. Mar. Biol. Assoc. U.K., 12: 468-505.

GARDNER, M. G., and R. D. WARD. 1998. Population structure of the Australian gummy shark (Mustelus antarcticus Gunther) inferred from allozymes, mitochondrial DNA and vertebrae counts. Mar. Freshw. Res., 49(7): 733-745.

GAULD, J. A. MS 1979. Reproduction and fecundity of the Scottish Norwegian stock of Spurdogs, Squalus acanthias (L.). ICES C.M. Doc., No. 1979/H:54, 15 p.

1989. Recordings of porbeagles landed in Scotland, with observations on the biology, distribution and exploitation of the species. DAFS, Edinburgh, Scott. Fish. Res. Rep., 45: 1-13.

GILBERT, P. W., and G. W. HEATH. 1972. The clasper-siphon sac mechanism in Squalus acanthias and Mustelus canis. Comp. Biochem. Physiol., 42A: 97-119.

GIRARD, M. 2000. Distribution et reproduction de deux espèces de requins de grands fonds, les «sikis», Centrophorus squamosus et Centroscymnus coelolepis exploités dans l'Atlantique Nord-Est. Rennes: L'Ecole Nationale Superieure Agronomique de Rennes, These de Docteur, $214 \mathrm{p}$.

GORDON, J. D. M. MS 1999. Management considerations of deep-water shark fisheries. In: Case studies of the management of elasmobranch fisheries. R. Shotton (ed.). FAO Fish. Tech. Pap., 378: 774-818.

GRANT, W. S., and F. M. UTTER. 1984. Biochemical population genetics of Pacific herring (Clupea pallasi). Can. J. Fish. Aquat. Sci., 41: 856-864.

GUBANOV, E. P. 1976. Sharks of the equatorial zone of the Indian Ocean. Candidates Abstract, Institute of Biology of the Southern Sea, 27 p. (in Russian).

HARDEN JONES, F. R. 1968. Fish migration. Edward Arnold Ltd, London, $325 \mathrm{p}$.

HAREIDE, N.-R., and G. GARNES. 2001. The distribution and catch rates of deep water fish along the Mid-Atlantic Ridge from 43 to $61^{\circ}$ N. Fish. Res., 51: 297-310.

HARRIS, J. E. 1952. A note of the breeding season, sex ratio and embryonic development of the dogfish Scyliorhinus canicula (L.). J. Mar. Biol. Assoc. U.K., 31: 269-274.

HAZIN, F. H. V., R. LESSA, M. ISHINA, K. OTSUKA, and K. KIHARA. 1991. Morphometric description of the blue shark, Prionace glauca, from the southwestern equatorial Atlantic. J. Tokyo Univ. Fish., 78(2): 137-144.

HEIST, E. J. 1999. A Review of Population Genetics in Sharks. In: Life in the Slow Lane: Ecology and Conservation of Long-Lived Marine Animals. J. A. Musick (ed.). Amer. Fish. Soc. Sym., 23: 161-168.

HEIST, E. J., and J. R. GOLD. 1999. Genetic identification of sharks in the U.S. Atlantic large coastal shark fishery. Fish. Bull., 97(1): 53-61.

HEIST, E. J., J. A. MUSICK, and J. E. GRAVES. 1996a. Genetic population structure of the shortfin mako (Isurus oxyrinchus) inferred from restriction fragment length polymorphism analysis of mitochondrial DNA. Can. J. Fish. Aquat. Sci., 53(3): 583-588.

1996b. Mitochondrial DNA diversity and divergence among sharpnose sharks, Rhizoprionodon terraenovae, from the Gulf of Mexico and Mid-Atlantic Bight. Fish. Bull., 94(4): 664-668.

HENDERSON, A. C., and A. CASEY. 2001. Reproduction and growth in the lesser-spotted dogfish Scyliorhinus canicula (Elasmobranchii: Scyliorhinidae), from the west coast of Ireland. Cah. Biol. Mar., 42(4): 397-405

HEUPELL, M. R., and M. B. BENNETT. 1997. Histology of dart tag insertion sites in the epaulette shark. J. Fish Biol., 50: 1034-1041.

HICKLING, C. F. 1930. A contribution towards the life-history of the spurdog. J. Mar. Biol. Assoc. U.K., 16: 529-576.

HISAW, F. L., and A. ALBERT. 1947. Observations on the 
reproduction of the spiny dogfish, Squalus acanthias. Biol. Bull., 92: 187-199.

HJERTENES, P. O. MS 1980. The spurdogs (Squalus acanthias) in the North Sea area: The Norwegian fishery and observations on changes in migration pattern. ICES C.M. Doc., No. 1980/H:60: 18 p.

HOLDEN, M.J. 1965. The stocks of spurdogs (Squalus acanthias L.) in British waters and their migrations. Fish. Investiga., Series II, 24(4), MAFF, London, 20 p.

1967a. Transatlantic movement of a tagged spurdogfish. Nature, 214: 1140-1141.

1967b. Spurdogs. MAFF Fisheries Laboratory, Lowestoft, Lab. Leaflet (New Series), 23 p.

1968. The rational exploitation of the ScottishNorwegian stock of spurdogs (Squalus acanthias L.). Fish. Investig., Series II, 25(8), MAFF, London, 27 p.

1972 The growth rates of Raja brachyura, $R$. clavata and $R$. montagui as determined from tagging data. ICESJ. Con., 34: 161-168.

1975 The fecundity of Raja clavata in British waters. ICES J. Con., 36: 110-118.

HOLDEN, M. J., and MEADOWS, P.S. 1962. The structure of the spine of the spurdog fish (Squalus acanthias L.) and its use for age determination. J. Mar. Biol. Assoc. U.K., 42: 179-197.

1964. The fecundity of the spurdog (Squalus acanthias L.). ICES J. Con., 28: 418-424.

HOLDEN, M. J., D. W. ROUT, and C. N. HUMPHREYS. 1971. The rate of egg laying by three species of ray. ICES J. Con., 33: 335-339.

IHSSEN, P. E., H. E. BOOKE, J. M. CASSLEMAN, J. MCGLADE, N. R. PAYNE, and F. M. UTTER. 1981. Stock identification: materials and methods. Can. J. Fish. Aquat. Sci., 38: 1838-1855.

JAMIESON, A. 1974. Genetic 'tags' for marine fish stocks. In: Sea Fisheries Research. F. R. Harden Jones (ed.). Elek Science, London, p. 91-99.

JARDAS, I. 1973. A contribution to our knowledge of the biology and ecology of thornback ray (Raja clavata L.) and brown ray (Raja miraletus) in the Adriatic. Acta Adriatica, 15(3): $1-42$.

1975. The morphometry and population diagnosis of thornback ray, Raja clavata L., in the Adriatic. Acta Adriatica, 17(5): 1-25.

1979. Morphological, biological and ecological characteristics of the lesser spotted dogfish, Scyliorhinus canicula (Linnaeus, 1758) population in the Adriatic Sea. Institut Oceanogr. Ribar. Split. Biljeske, IV(2-3).

JENNINGS, S., S. P. R. GREENSTREET, and J. D. REYNOLDS. 1999. Structural change in an exploited fish community: a consequence of differential fishing effects on species with contrasting life histories. J. Anim. Ecol., 68: 617-627.

KABATA, Z. 1979. Parasitic Copepoda of British Fishes. The Ray Society, London, 468 p. (+ plates).

KETCHEN, K. S. 1972. Size at maturity, fecundity and embryonic growth of the spiny dogfish (Squalus acanthias) in British Columbia waters. J. Fish. Res. Board Can., 29: $1717-1723$.

KIRNOSOVA, I.P. 1989. Reproduction of spiny dogfish, Squalus acanthias in the Black Sea. J. Ichthyol., 29(3): 21-26.

KNIJN, R. J., T. W. BOON, H. J. L. HEESSEN, and J. R. G. HISLOP. 1993. Atlas of North Sea fishes. ICES Cooper. Res. Rep., 194.

KOHLER, N. E., J. G. CASEY, and P. A. TURNER. 1998. NMFS cooperative shark tagging program, 1962-1993: An atlas of shark tag and recapture data. Mar. Fish. Rev., 60(2): 1-87.

KOHLER, N. E., and P. A. TURNER. 2001. Shark tagging: a review of conventional methods and studies. Env. Biol. Fishes, 60: 191-223.

LAM, T. J. 1983. Environmental influences on gonadal activity in fish. In: Fish Physiology Volume IX, Part B: Reproduction. W. S. Hoar, D. J. Randall and E. M. Donaldson (eds.). Academic Press. New York. London.

LAVERY, S., and J. B. SHAKLEE. 1989. Population genetics of two tropical sharks, Carcharhinus tilstoni and C. sorrah, in northern Australia. Aust. J. Mar. Freshw. Res., 40(5): 541-557.

LEAH, R., S. EVANS, and M. JOHNSON. 1991a. Mercury in muscle tissue of lesser-spotted dogfish (Scyliorhinus canicula) from the Northeast Irish Sea. Sci. Total Envir., 108: $215-224$.

LEAH, R. T., S. J. EVANS, M. S. JOHNSON, and S. COLLINGS. 1991b. Spatial patterns in accumulation by fish from the NE Irish Sea. Mar. Pollut. Bull., 22(4): 172-175.

LELOUP, J., and M. OLIVEREAU. 1951. Donnèes biomètriques comparatives sur la rousette (Scyllium canicula L.) de la Manche et de la Mèditerranèe. Vie et Milieu, 2: 2 p.

LESTER, R. J. G. 1990. Reappraisal of the use of parasites for fish stock identification. Aust. J. Mar. Freshw. Res. 41: $855-864$.

LITVINOV, F. F. 1982. Two forms of teeth in blue shark, Prionace glauca (Carcharhinidae). J. Ichthyol., 22(4): 154-156.

MACKENZIE, K., and P. ABAUNZA. 1998. Parasites as biological tags for stock discrimination of marine fish: a guide to procedures and methods. Fish. Res., 38: 45-56.

MACNAUGHTON, R., E. ROGAN, V. HERNANDEZGARCIA, and C. LORDAN. MS 1998. The importance of cephalopods in the diet of blue shark (Prionace glauca) south and west of Ireland. ICES C.M. Doc., No. 1998/ M:7: $12 \mathrm{p}$.

MAGNÚSSON, J., J. V. MAGNÚSSON, and K. B. JAKOBSDÓTTIR. 2000. Deep-sea fishes, Icelandic contributions to the deep water research project, EC Fair Project CT 95-0655, 1996-1999. Hafrannsóknastofnun Fjölrit NR. 76: $164 \mathrm{p}$.

MCEACHRAN, J. D., and S. BRANSTETTER. 1989. Squalidae. In: Fishes of the Northeastern Atlantic and the Mediterranean Vol. 1, P. J. P.Whitehead, M.-L.Bauchot, J.-C.Hureau, J. Nielsen, and E. Tortonese (eds.). UNESCO, Paris, 128-147.

MCKENZIE, R. A. and S. N. TIBBO. 1964. A morphometric description of blue shark (Prionace glauca) from Canadian Atlantic waters. J. Fish. Res. Board Can., 21(4): 865-866.

MCVICAR, A. H. 1977. Intestinal helminth parasites of the ray Raja naevus in British waters. J. Helminthol., 51: 11-21.

MEJUTO, J. MS 1985. Associated catches of sharks, Prionace 
glauca, Isurus oxyrinchus and Lamna nasus, with NW and N Spanish swordfish fishery in 1984. ICES C.M. Doc., No. 1985/H:42: $16 \mathrm{p}$.

MELLINGER, J., and F. WRISEZ. 1984. Caractéres biomètriques distintifs de l'embryon et des ses annexes chez la roussette de la Manche, comparèe a celle de la Mediterraneet determination precise. Cah. Biol. Mar., 25: 305-317.

MERRET, N. R., R. L. HAEDRICH, J. D. M. GORDON, and M. STEHMANN. 1991. Deep demersal fish assemblage structure in Porcupine Seabight (Eastern north Atlantic): slope sampling by three different trawls compared. J. Mar. Biol. Assoc. U.K., 71: 359-374.

METCALFE, J. D., and G. P. ARNOLD. 1997.Tracking fish with electronic tags. Nature, 387: 665-666.

MOORE, A. B. M. 2001. Metazoan parasites of the lesserspotted dogfish Scyliorhinus canicula and their potential as stock discrimination tools. J. Mar. Biol. Ass. U.K., 81: 1009-1013.

MORENO, J. A. 1995. Guía de tiburones de aguas ibéricas, Atlántico Nororiental y Mediterráneo. S. A. Pirámide (ed.). $310 \mathrm{p}$.

MUÑOZ-CHAPULI, R. 1984. Ethologie de la reproduction chez quelques requins de l'Alantique nord-est. Cybium, 8: $1-14$.

MUÑOZ-CHAPULI, R., J. M. GARCIA GUZMAN, and A. V. De ANDRES. 1984. Scyliorhinus canicula en el Atlántico y Mediterráneo. Introducción a un estudio de poblaciones. Butll. Soc. Ictio. Herp., 9: 4-9.

MUNOZ, P. D., and E. R. MARCOTE. 2001. The Spanish multi-species deep-sea fishery on Hatton Bank (North East Atlantic): 1996-2000. NAFO SCR Doc., No. 120, Serial No. N4508, $20 \mathrm{p}$.

NAMMACK, M.F., J.A. MUSICK, and J.A. COLVOCORESSES. 1985. Life-history of spiny dogfish off the Northeastern United States. Trans. Am. Fish. Soc., 114(3): 367-376.

NOTTAGE, A. S., and E. J. PERKINS. 1983. Growth and maturation of roker, Raja clavata L. in the Solway Firth. J. Fish Biol., 23: 43-48.

OLSEN, A. M. 1984. Synopsis of biological data on the school shark Galeorhinus australis (Macleay 1881). FAO Fish. Synop., No. 139, 42 p.

PARDINI, A. T., C. S. JONES, L. R. NOBLE, B. KREISER, H. MALCOLM, B. D. BRUCE, J. D. SEVENS, G. CLIFF, M. C. SCHOLL, M. FRANCIS, C. A. J. DUFFY, and A. P. MARTIN. 2001. Sex-biased dispersal of great white sharks. Nature, 412(6843): 139-140.

PARKER, R. R., E. C. BLACK, and P. A. LARKIN. 1963. Some aspects of fish-marking mortality. ICNAF Spec. Pub., 4: 117-122.

PARSONS, G. R. 1993. Geographic variation in reproduction between two populations of the bonnethead shark, Sphyrna tiburo. In: The reproduction and development of sharks, skates, rays and ratfishes. J. P. Wourms and L. S. Demski (eds.). Environ. Biol. Fish., 38(1-3): 25-35.

PASTOORS, M. A. 2004. Stock assessments of elasmobranchs in the Northeast Atlantic: making the most of the data.

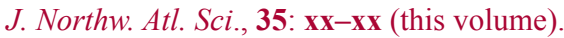

PAWSON, M. G., and S. JENNINGS. 1996. Mini review: A critique of methods for stock identification in marine capture fisheries. Fish. Res., 25: 203-217.

PAWSON, M. G., D. F. KELLEY, and G. D. PICKETT. 1987. The distribution and migrations of bass Dicentrarchus labrax L. in waters around England and Wales as shown by tagging. J. Mar. Biol. Ass. U.K., 67: 183-217.

PRATT, H.L. 1979. Reproduction in the blue shark, Prionace glauca. Fish. Bull., 77(2): 445-470.

QUERO, J.-C., J. DARDIGNAC, and J. J. VAYNE. 1989. Les poissons du Golfe de Gascogne. IFREMER. Brest. $229 \mathrm{p}$.

QUINTERO, A. P. 1990. Helmintos parásitos de peces de las costas gallegas. Tesis doctoral. Universdad de Santiago. Facultad de Farmacia. Departamento de Microbiologia y Parasitologia.

RODRIGUEZ-CABELLO, C., F. DE LA GANDARA, and F. SANCHEZ. 1997. Preliminary results on growth and movements of dogfish Scyliorhinus canicula (Linnaeus, 1758) in the Cantabrian Sea. Oceanolog. Acta, 21: 363-370.

RODRIGUEZ-CABELLO, C., F. VELASCO, and I. OLASO. 1998. Reproductive biology of lesser spotted dogfish Scyliorhinus canicula (L., 1758) in the Cantabrian Sea. Sci. Mar, 62: 187-191.

RODRIGUEZ-CABELLO, C., F. SANCHEZ, A. FERNANDEZ, and I. OLASO. MS 2001. Is the lesser spotted dogfish (Scyliorhinus canicula) from the Cantabrian sea, a unique stock? ICES C.M. Doc., No. 2001/O:06.

ROKICKI, J., and D. BYCHAWSKA. 1991. Parasitic copepods of Carcharhinidae and Sphyridae (Elasmobranchia) from the Atlantic Ocean. J. Nat. Hist., 26(6): 1439-1448.

ROUSSET, J. 1990. Population structure of Thornback Rays Raja clavata and their movements in the Bay of Douarnenez. J. Mar. Biol. Assoc. U.K., 70: 261-268.

RYLAND, J. S., and T. O. AJAYI. 1984. Growth and population dynamics of three Raja species (Batoidei) in Carmarthen Bay, British Isles. ICES J. Con., 41: 111-120.

RYMAN, N. 1991. Conservation genetics considerations in fisheries management. J. Fish Biol., 39(Suppl. A): 211-224.

RYMAN, N., U. LAGERCRANTZ, L. ANDERSSON, R. CHAKRABORTY, and R. ROSENBERG. 1984. Lack or correspondence between genetic and morphological variability in patterns in Atlantic herring (Clupea harengus). Heredity, 53: 687-704.

SANCHEZ, F. 1993. Las comunidades de peces de la plataforma del Cantabrico. Publ. Esp. Inst. Esp. Oceanogr., 13: $137 \mathrm{p}$.

SANCHEZ, F., F. De LA GANDARA, and R. GANCEDO, R. 1995. Atlas de los peces demersales de Galicia y Cantábrico. Otoño 1991-1993. Publ. Esp. Inst. Español de Ocean., 20: $100 \mathrm{p}$.

SANMARTIN, M. L., P. QUINTEIRO, and F. M. UBEIRA. 1989. Nematode parasites of commercially important fish in NW Spain. Dis. Aquat. Org., 7: 75-77.

SCHOLZ, T., L. EUZET, and F. MORAVEC. 1998. Taxonomic status of Pelichnibothrium speciosum Monticelli, 1889 (Cestoda: Tetraphyllidea), a mysterious parasite of Alepisaurus ferox Lowe (Teleostei: Alepisauridae) and Prionace glauca (L.) (Euselachii: Carcharinidae). Syst. 
Parasitology, 41(1): 1-8.

SEBER, G. A. F. 1973. The estimation of animal abundance. Griffen, London, $506 \mathrm{p}$.

SIMS, D. W., E. J. SOUTHALL, A. J. RICHARDSON, P. C. REID, and J. D. METCALFE. 2003. Seasonal movements and behaviour of basking sharks from archival tagging: no evidence of winter hibernation. Mar. Ecol. Prog. Ser., 248: $187-196$.

SMITH, P. J. 1986. Low genetic variation in sharks (Chondrichthyes). Copeia, 1986(1): 202-207.

SOSINSKI, J. 1977. Polish investigations on the Scottish Norwegian spurdog (Squalus acanthias) in 1974. Ann. Biol.(Cph), 1975, 32: 178-179.

SPRINGER, V. G., and J. A. F. GARRICK. 1964. A survey of vertebral numbers in sharks. Proc. U.S. Nat. Mus., 116: $73-96$.

STEHMANN, M., and D. L. BÜRKEL. 1989. Rajidae. In: Fishes of the Northeastern Atlantic and the Mediterranean. P. J. P. Whitehead, M.-L. Bouchot, J.-C. Hureau, J. Nielsen, and E. Tortonese (eds.), UNESCO, Paris, p. 163-196.

STEVEN, G. A. 1932. Rays and skates of Devon and Cornwall II Study of the fishery; with notes on the occurrence migrations and habits of the species J. Mar. Biol. Assoc. U.K., 18: 1-33.

1933 Rays and Skates of Devon and Cornwall III. The proportions of the sexes in nature and in commercial landings, and their significance to the fishery. J. Mar. Biol. Assoc. U.K., 18: 611-625.

1934. Observations on the growth of the claspers and cloaca in Raja clavata Linnaeus. J. Mar. Biol. Assoc. U.K., 19: 887-899.

1936. Migrations and growth of the thornback ray (Raja clavata L.). J. Mar. Biol. Assoc. U.K., 20: 605-614.

STEVENS, J. D. 1974. The occurrence and significance of tooth cuts on the blue shark (Prionace glauca L.) from British waters. J. Mar. Biol. Assoc. U.K., 54: 373-378.

1975. Vertebral rings as a means of age determination in the blue shark (Prionace glauca). J. Mar. Biol. Assoc. U.K., 55: 657-665.

1976a. First results of shark tagging in the Northeast Atlantic, 1972-1975. J. Mar. Biol. Assoc. U.K., 56: 929-937.

1976b. The Ecology of the Blue Shark (Prionace glauca L.) in British Waters. Unpublished Ph.D. Thesis, University of London.

1990. Further results from a tagging study of pelagic sharks in the Northeast Atlantic. J. Mar. Biol. Assoc. U.K., 70(4): 707-720.

STRASBURG, D. W. 1958. Distribution, abundance and habits of pelagic sharks in the central Pacific Ocean. Fish. Bull. Fish Wildl. Ser, 58: 335-261.

SUDA, A. 1953. Ecological studies on the blue shark (Prionace glauca). South Sea Area Fish. Res. Lab. Rep., 26: 1-11 (in Japanese).

SUMPTER, J. P., and J. M. DODD. 1979. The annual reproductive cycle of the female lesser spotted dogfish, Scyliorhinus canicula L., and its endocrine control. J. Fish Biol., 15: 687-695.
SUNDSTRÖM, L. F., S. H. GRUBER, S. M. CLERMONT, J. P. S. CORREIA, J. R. C. DE MARIGNAC, J. F. MORRISSEY, C. R. LOWRANCE, L. THOMASSEN, and M. T. OLIVEIRA. 2001. Review of elasmobranch behavioural studies using ultrasonic telemetry with special reference to the lemon shark, Negaprion brevirostris, around Bimini Islands, Bahamas. Environ. Biol. Fish., 60(1-3): 225-250.

TANAKA, T., G. M. CAILLIET, and K. G. YUDIN. 1990. Differences in growth of the blue shark, Prionace glauca: Technique or population? In: Elasmobranchs as living resources: Advances in the biology, ecology, systematics, and the status of the fisheries. H. L. Pratt, S. H. Gruber and T. Taniuchi (eds.). U.S. Dept. Comm., NOAA Tech. Rep., No. NMFS 90: 177-187.

TANIUCHI, T. and H. TACHIKAWA. 1999. Geographical variation in age and growth of Squalus mitsukurii (Elasmobranchii: Squalidae) in the North Pacific. In: Proceedings of the $5^{\text {th }}$ Indo-Pacific Fish conference, Noumea, New Caledonia, 3-8 November 1997. B. Seret, and J. Y. Sire(eds.). Societe Francaise d'Ichtyologie, Paris (France), p. 321-328.

TEMPLEMAN, W. 1954. Migrations of spiny dogfish tagged in Newfoundland waters. J. Fish. Res. Board Can., 11(4): 351-354.

1976. Transatlantic migrations of spiny dogfish (Squalus acanthias). J. Fish. Res. Board Can., 33: 2605-2609.

1984. Migrations of spiny dogfish, Squalus acanthias, and recapture success from tagging in the Newfoundland area, 1963-65. J. Northw. Atl. Fish. Sci., 5(1): 47-53.

TSANG, P. C. W., and I. P. CALLARD. 1987. Morphological and endocrine correlates of the reproductive cycle of the aplacental viviparous dogfish, Squalus acanthias. Gen. Comp. Endocrinol., 66(2): 182-189.

TUCKER, D. W., and C. T. NEWNHAM. 1957. The blue shark Prionace glauca (L.) breeds in British seas. Ann. Magaz. Nat. Hist., 10: 673-687.

UTTER, F. M. 1991. Biochemical genetics and fishery management: an historical perspective. J. Fish Biol., 39(Suppl. A): 1-20.

VAS, P. 1995. The status and conservation of sharks in Britain. Aquat. Conserv.: Mar. Freshw. Ecosystems, 5: 67-79.

VERISSIMO, A., L. GORDO, and I. FIGUEIREDO. 2003. Reproductive biology and embryonic development of Centroscymnus coelolepis in Portuguese mainland waters ICES J. Mar. Sci., 60(6): 1335-1341.

VINCE, M. R. 1991. Stock identity in spurdog (Squalus acanthias L.) around the British Isles. Fish. Res., 12: 341-354.

WALKER, P. A. 1998 to 1999. Fleeting images: Dynamics of North Sea Ray populations. PhD Thesis, University of Amsterdam, the Netherlands, $145 \mathrm{p}$.

WALKER, P. A., and H. J. L. HEESSEN. 1996. Long-term changes in ray populations in the North Sea. ICES J. Mar. Sci., 53: 1085-1093.

WALKER, P. A., G. HOWLETT, and R. MILLNER. 1997. Distribution, movement and stock structure of three ray species in the North Sea and eastern English Channel. ICES 
J. Mar. Sci., 54: 797-808.

WATSON, D. E., and T. B. THORSON. 1976.Helminths from elasmobranchs in Central American fresh waters. In: Investigations of the chthyofauna of Nicaraguan lakes. T. B. Thorson (ed.). University of Nebraska, Lincoln, p. 629-640.

WEST, G. J., and J. D. STEVENS. 2001. Archival tagging of school shark, Galeorhinus galeus in Australia: initial results. Env. Biol. Fishes, 60: 283-298.

WHEELER, A. 1978. Key to the fishes of northern Europe. Frederick Warne, London. $350 \mathrm{p}$.

WILLIAMS, H. H., K. MACKENZIE, and A. M. MCCARTHY. 1992. Parasites as biological indicators of the population biology, migrations, diet, and phylogenetics of fish. Rev. Fish Biol. Fish., 2: 144-176.

WISE, J. P. 1963. Factors affecting number and quality of returns from tagging cod with different tags and using different methods of capture in ICNAP Divisions 4X and 5Y in 1957. ICNAF Spec. Pub., 4: 101-105.

ZUPANOVIC, S. 1961. Contribution a la connaissance de la biologie des poissons d l'Adriatique. Acta Adriatique 9: $84 \mathrm{p}$.

XIAO, Y., L. P. BROWN, T. I. WALKER, and A. E. PUNT. 1999. Estimation of instantaneous rates of tag shedding for school shark, Galeorhinus galeus, and gummy shark, Mustelus antarcticus, by conditional likelihood. Fish. Bull., 97: $170-184$. 
